very slight nodule left. May 4, all signs of trouble have entirely disappeared.

CASE 5.-J. P., 22 years old, was seen March 24. He had had epididymitis for three days, gonorrhea two weeks, primary attack. Epididymis large and painful.

Treatment.-First injection (175). March 26, better, no spontaneous pain, swelling reduced one third; second injection (181). March 28, pain very slight, no injection. March 30, still improving, no injection. April 28, slight nodule still left

CASE 6.-W. W., was seen March 31. He had had internal medication for thirty-one days; primary attack. Patient drove a truck and did heavy lifting. He had had epidid-mitis for 24 bours, swelling slight, but pain intense.

Treatment.-First injection (187). April 2, no pain when quiet, but great pain when he moved about or rode in the cars (patient came a long distance for treatment, from East New York); second injection (187). April 6, no injection, as both arms were swollen; swelling in epididymis was enormous. April 9, less pain in testicle on handling, swelling reduced onehalf. April 16, beginning pain in right epididymis - third injection (187) ; left side still improving. April 19, right side all right, no trace of trouble on that side, but left side had again increased in size; pain returned to some degree on moving. April 26, left epididymitis greatly improved, but cord had become involved and very painful at inguinal ring; fourth injection (goat serum). May 3 , pain at inguinal ring greatly diminished fifth injection (goat). Swelling in epididymis reduced one-half again. Patient took a hot bath every other day. May 17, he had had no pain for two weeks, the swelling was soft, but large, no hard nodules; patient returned to work. May 23, he felt all right. This case was the worst of the series; nevertheless, patient made a distinct gain after each injection. The necessary long car ride was a great handicap.

CASEs 7 and 8. - The next two patients received only one injection each. One was sent, by his own request, to the hospital, as he could not remain at hoine without working. The other did not retum.

Case 9.-B. R., 27 years old, was seen April 27. $\mathrm{He}$ had had gonorrhea three weeks; epididymitis 24 hours, swelling large and painful.

Treatment.-First injection (200). April 28, patient said he felt better; no pain, size the same; second injection (200). April 30, no pain, swelling reduced to one-third of former size; third injection (200). May 2, no pain, nodule only left; fourth injection (200). Patient went to work. May 7 , slight return of pain and swelling; fifth injection (200). May 9 , no pain; patient continued at work. May 12 , slight induration left in tail of epididymis, but no swelling of tissues surrounding it and no pain. May 19, no trace in epididymis.

CAse 10.-J. F., 19 years old, was seen May 10. He had had gonorrhea three weeks, primary attack, and epididymitis 24 hours. Epididymis was very painful, pain running up to inguinal ring. Process in early stage.

Treatment.-First injection (goat). May 11, on coming to the dispensary patient felt no pain, but was obliged to wait an hour before my arrival; he became restless and pain set in again; second injection (goat). May 12, no pain, swelling in epididymis of moderate size; no injection. May 15, not seen for three days, pain again returned slightly. Epididymis was more swollen, but not very tender to pressure; third injection (goat). May 16, one week since beginning of attack; no pain, swelling reduced, no injection. May 17 , no pain, patient felt perfectly well. Nodulation was very slight; patient not seen since.

CAse 11.-S. W., 21 years old, seen on May 10, had had gonorrhea two months (multiple attack), epididymitis three days. It began slowly and insidiously, was then very painful, but not much swelling.

Treatment.-First injection (goat). May 14, swelling almost gone. No pain. Testicle painted with ichthyol and glycerin, equal parts, dressing applied; no injection. May 16, patient felt so well yesterday that he went to work. At night had return of severe pain in epididymis and cord, and complains of severe spontaneous pain. Tenderness in bandling not mirked and there is only slight swelling; second injection (goat). May 17 , pain greatly diminished, very little swelling; third injec- tion (goat). No further injection made after this; when last seen, very slight thickening of epididymis noted.

CAse 12.-H. L., 35 years old, was seen May 15. Eight years ago had epididymitis with an attack of gonorrhea. Present attack of gonorrhea began four weeks ago; epididymitis began yesterday. Two injections were made with goat serum on May 15 and 16. May 17, almost no pain, swelling much smaller. May 22, only slight thickening, no pain.

CASE 13.-M. F., 28 years old, was seen May 22. He had had several attacks of gonorrhea. Present attack began five weeks ago. He never had epididymitis before the day previous. $\mathrm{He}$ complained of great pain, but process was in early stage, not much involvement. Two injections were given with goat serum on May 22 and 23. May 24, no pain, very slight trace of thickening. May 28, no trace.

64 East Fifty-sixth Street.

\section{LEGISLATION FOR VITAT STATISTICS IN THE UNITED STATES.}

\section{CRESSY L. WILBUR, M.D.}

Chief Statistician, Division of Vital Statistics, Bureau of the Census, Department of Commerce and Labor, U. S. Government. WASHINGTON, D. C.

The condition of registration of vital statistics in the United States has long been a reproach to this country. In a recent discussion in the Royal Statistical Society of England a speaker casually remarked: "In the United States the vital statistics are almost worthless." And he was right, so far as concerns vital statistics covering the country as a whole, and showing, as do those of other civilized countries, the birth rates and death rates from year to year.

The importance of vital statistics, both from a legal standpoint and for the purpose of effective sanitary administration, is not altogether overlooked by us. Certain states have long made effective use of such data. One of the oldest and most efficient systems of registration in this country is that of New Hampshire, and Dr. Irving A. Watson, secretary of the State Board of Health, says in his last report:

All sanitary calculations are based on vital statistics. With. out them health officers would be groping in the dark so far as the results of their work are concerned. Sanitary legislation would be largely of a hit-or-miss character. Scientific methods could not be formulated for the suppression of disease. The importance of a given malady as a cause of death could not be determined-in fact, vital statistics are the measure by which we gauge and weigh, with approximate exactness, the movement of a population; whether inereasing or diminishing, the mortality from different causes, the effect of seasons, climate, occupation, locality, and other environments on which the health of individuals and communities depends.

The health authorities of Pennsylvania, after long experience in attempting to do sanitary work without a well-equipped system of registration as a basis, adopted the following resolution which has since resulted in the enactment of one of the best registration laws now on the statute books of any state and the admission of Pennsylvania into the registration area:

Resolved, That the achievement of the registration of all deaths, with their causes, immediately after their occurrence, and the prompt return of certificates of death from local registrars directly to the central bureau of vital statistics which shall constitute a part of the organization of the State Board of Health, thereby giving the sanitary authorities of the state timely information of the exact prevalence and distribution of disease, is the most important of all sanitary measures and should be unremittingly urged until successfully carried out in this state. 
While we have no vital statistics for the United States as a whole, we have returns of deaths from certain states having effective laws and from certain cities in nonregistration states where there has been effective local registration. It is gratifying to know that the proportion of population thus represented in what is called the "registration area" is increasing, as shown by the following statement:

\begin{tabular}{|c|c|c|c|}
\hline Year. & $\begin{array}{l}\text { Population of } \\
\text { continental } \\
\text { Onited States. }\end{array}$ & $\begin{array}{c}\text { Populatiou of } \\
\text { registration } \\
\text { area. }\end{array}$ & Per cent. \\
\hline 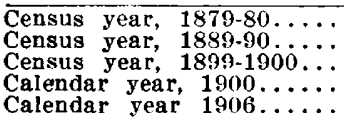 & 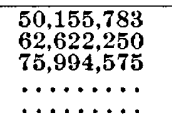 & $\begin{array}{r}8,538,366 \\
19,659,440 \\
28,8167,269 \\
* 30,765,618 \\
* 36,846,981\end{array}$ & $\begin{array}{r}17.0 \\
31.4 \\
37.9 \\
* 40.5 \\
* 48.5\end{array}$ \\
\hline
\end{tabular}

* Population and percentage according to census of 1900.

We have thus reached a point where nearly one-half of the entire population of the United States is represented by mortality statistics, and if we pay suitable attention during the next few years to the enactment of wise legislation in the various states not yet included in the registration area this proportion should be largely. increased and the time be in sight when the entire United States shall possess adequate registration of deaths.

In the appended tabular exhibit may be seen just what states constituted the registration area in 1900 , and how many have been added since that date. The column showing those not yet accepted as registration states is of special interest, since in many of them inadequate or ineffective laws for this purpose now exist, and in a large number of them the legislatures are now in session, by which proper laws or amendments to existing laws can be enacted.

HOW CAN THE MEMBERS OF THE AMERICAN MEDICAL ASSOCIATION AID?

Briefly, the members of the American Medical Association can be of great service in helping to advance the day of reliable vital statistics in this country in two general ways: (1) By encouraging and helping the state authorities, chiefly members of the state boards of health, who are now advocating the adoption of effective legislation; (2) by discouraging the adoption of measures that experience has shown to be wholly inadequate for the purpose for which they are proposed. Some physicians and members of this Association are also member's of state legislatures, and as such may be able to render very effective service in helping to secure good and to ward off bad legislation for vital statistics.

As to the interest of the Association as an organization, I am glad to say that the accurate registration of vital statistics was one of the very first objects which it desired to promote. I find in Vol. I of the Transactions of the Association, for 1848, a report "on behalf of the Standing Committee on Registration of Births, Marriages and Deaths," in which reference is made to an address which was adopted during the preceding year and transmitted, in accordance with the instructions of the Association, to the "authorities of all the United States." Many reports were made by this committee and much of value was accomplished before the Civil War interrupted their labors. I can do no better than to quote and emphasize the concluding paragraphs of the report submitted under date of April 25, 1858, by Dr. Edward Jarvis, "one of the committee on registration":
"As now this system [of registration of vital statistics] is well established and in operation, in Kentucky, South Carolina, Virginia, New Jersey, Connecticut, Rhode Island, Massachusetts and Vermont, eight states, and as Maine and Michigan have taken the preliminary steps for this purpose, and men of science, and even politicians, are using their influence in other states for this object, there is much reason to believe that their example will be followed, and that state after state will, in the progress of time, follow in the same path, until finally, and, we trust, at no distant period, the system will be adopted, and this record of life and death be made complete, throughout our nation.

"It will be necessary for this purpose that the Association bodily, and all of its members individually, publicly and privately, at home and everywhere, use their influence unceasingly until the whole is accomplished."

It is interesting to note that the first three states named by Dr. Jarvis are southern states, although not a single southern state belongs to the registration area to-day. The health authorities of Virginia, however, recently adopted a resolution similar to that adopted by Pennsylvania, and bills for the registration of vital statistics will be introduced during the present legislative sessions in North Carolina and perhaps in other southern states. It is of great importance that this section of the Union should be adequately represented. Organic laws or amendatory acts are contemplated for Missouri, Kansas, Minnesota, Wisconsin, North Dakota, Montana, and Washington, besides a reference to the subject in the constitution of the new state of Oklahoma under which effective legislation can later be enacted.

\section{WHAT ARE THE NECESSARY PROVISIONS OF A REGISTRA- TION LAW FOR DEATHS?}

Experience has shown that certain methods will give satisfactory results for the registration of deaths in this country, and that certain methods will not. Is it wiser to adopt methods that have been tested and uniformly found to give good results, or to adopt certain other methods, that have likewise been tested again and again, and uniformly proved to be worthless? Theoretically this proposition ought not to require much argument, but in practice it does; the same old ineffective plans are still brought forward to-day, and the statute bonks of certain states are likely to be cumbered with so-called vital statistics laws that can not possibly prove other than futile and absurd.

Following are the necessary elements of a satisfactory registration law for deaths, as formulated by a committee of practical registration officials representing the American Public Health Association and coöperating with the Burcau of the Census, and which, since their publication in 1901, have afforded a safe and efficient guide for legislation and have greatly aided in the extension of the registration area:

1. Deaths must be registered immediately after their occurrence.

2. Certificates of death (standard form) should be required.

3. Burial or removal permits are essential to the enforcement of the law.

4. Efficient local registrars (properly compensated) are necessary.

5. The responsibility for reporting deaths to the local regis. trar should be fixed.

6. The central registration office should have full control of the local machinery, and its rules should have the effect of law.

7. The tranomission and preservation of records should be provided for.

8. Penalties should be provided (and enforced). 
In the above list, the two items neglect of which is most frequently responsible for failure are indicated by italies. The others are equally necessary, but when, in the examination of a law, it appears that there is no requirement for a burial or removal permit before any disposition is made of the body, or that no local registrars are provided, and properly compensated, by whom such permits can be issued, then it is seldom necessary to inquire further as to why deaths are not fully recorded. The burial permit is the absolutely necessary check on the registration of deaths and the only one by which efficient and complete operation of such a law can be secured. If registration is deferred, and undertakers are allowed to inter or to remove bodies without permits, with the understanding that the deaths shall be registered or enumerated at some subsequent time, the result will be that many deaths will never be registered. The immediate local registration of deaths, with the safeguard of a burial or removal permit, necessarily implies that there shall be a local registrar to receive the certificate of death and to issue the permit. This official should have a limited district, and should exercise supervision over it, under the general direction of the central registration office of the state. Only in this way can it be certain that no deaths escape registration through violation of the law, and the central office can thus be able to insure uniform and complete registration for the entire state area. Returns of the original certificates of deaths should be made monthly by the local registrar to the state registrar, affording the most authentic and satisfactory legal records and statistical data for sanitary purposes.

In lieu of this system it has been enacted many times, and always in vain, that deaths should be reported directly to the county health officer, county clerk or other county official. A county officer can not be expected to act as a local registrar of deaths, since it is unreasonable to expect that undertakers should take certificates of deaths to him from distant parts of a county and obtain permits before interment or removal. Physicians will not report deaths completely to a county officer. no matter what penalty is imposed. It is very undesirable that local registrars should report to any county officer, since it only results in delay in the transmission of the returns to the central registration office of the state and serves no good purpose whatever. A registration law can not be satisfactorily enforced through county officers, but only directly by the central office through the local registrars, each of the latter being thoroughly acquainted with and responsible for his limited district. County records may be maintained for legal purposes, if already existing, by means of transcripts or otherwise so that the system will not interfere, as at present, with successful registration.

I have entered somewhat into detail in regard to this matter, because the pernicious county system of attempting to collect vital statistics-it has never yet successfully collected them in a single one of the many states in which it has been tried-is one of the stumbling blocks that are continually thwarting efforts to secure adequate legislation. Its inherent unfitness for this purpose should be understood by all persons interested in better laws. This antiquated and discredited plan was a part of the old Pennsylvania law of 1851 . It resulted in utter failure, and it will be a failure if adopted by any state in its legislation of $190 \%$, as it has been time and time again in various states during the intervening years. There is no necessity for wasting further effort on measures that have invariably proved futile and which only hinder the adoption of proper laws. Hence the great advantage of having all such proposed legislation carefully studied by members of this Association who

\section{STATUS OF EFFECTIVE REGISTRATION OF DEATHS,} 1906.

\begin{tabular}{|c|c|c|c|c|c|}
\hline \multicolumn{2}{|c|}{ Registration States, 1900.} & \multicolumn{2}{|c|}{$\begin{array}{l}\text { Added as Registration } \\
\text { States, } 1906 .\end{array}$} & \multicolumn{2}{|c|}{$\begin{array}{c}\text { Not yet accepted as Reg- } \\
\text { istration States. }\end{array}$} \\
\hline State. & $\begin{array}{l}\text { Popula- } \\
\text { tion, } 1900 .\end{array}$ & State. & $\begin{array}{l}\text { Popula- } \\
\text { tion. } 1900 .\end{array}$ & State. & $\begin{array}{l}\text { Popula- } \\
\text { tion, } 1900 .\end{array}$ \\
\hline Connectjeut & 908,420 & $\begin{array}{l}\text { California. } \\
\text { Colorado. }\end{array}$ & $\begin{array}{r}1,485,053 \\
539,700\end{array}$ & $\begin{array}{l}\text { Alabama. } \ldots \\
\text { Arizona } \ldots \\
\text { Arkansas } \ldots\end{array}$ & $\begin{array}{r}1,828,697 \\
122,931 \\
1,311,564\end{array}$ \\
\hline Dis. of Col.. & 278,718 & & & Delaware .. & 184,735 \\
\hline Indiana. ... & $2,516,462$ & & & $\begin{array}{l}\text { Florida } \ldots \\
\text { Georgla. } \ldots \\
\text { Idabo } \ldots \\
\text { Illinois } \ldots \\
\text { Ind. Ter. } \ldots\end{array}$ & $\begin{array}{r}\mathbf{5 2 8 , 5 4 2} \\
2,216,331 \\
161,772 \\
4,821, \mathbf{5 5 0} \\
392,060\end{array}$ \\
\hline Maine $\ldots$. & 694,466 & & & $\begin{array}{l}\text { Lowa } \ldots \ldots \\
\text { Kansas } \ldots \\
\text { Kentucky } \\
\text { Loulstana }\end{array}$ & $\begin{array}{l}2,231,853 \\
1,470,495 \\
2,147,174 \\
1,381,625\end{array}$ \\
\hline $\begin{array}{l}\text { Mass. } . . . . \\
\text { Michigan } . .\end{array}$ & $\begin{array}{l}2,805,346 \\
2,420,982\end{array}$ & Maryland $\cdots$ & $1,188,044$ & & \\
\hline $\begin{array}{l}\text { New Hamp. } \\
\text { New Jersey. }\end{array}$ & $\begin{array}{r}\mathbf{4 1 1}, 588 \\
1,883,669\end{array}$ & & & $\begin{array}{l}\text { Minnesota. } \\
\text { Mississippi. } \\
\text { Missouri } \ldots \\
\text { Montana } \ldots \\
\text { Nebraska } \ldots \\
\text { Nevada .... }\end{array}$ & $\begin{array}{r}1,751,394 \\
1,551,270 \\
\mathbf{3 , 1 0 6 , 6 6 5} \\
\mathbf{2 4 3 , 3 2 9} \\
\mathbf{1 , 0 6 6 , 3 0 0} \\
42,335\end{array}$ \\
\hline New York... & $\mathbf{7 , 2 6 8 , 8 9 4}$ & Penna. & $6,302,115$ & $\left\{\begin{array}{l}\text { New Mexico. } \\
\text { N. Carolina. } \\
\text { N. Dakota. } \\
\text { Ohio ..... } \\
\text { Oklahoma } \\
\text { Oregon .... }\end{array}\right.$ & $\begin{array}{r}195,310 \\
1,893,810 \\
319,146 \\
4,157,545 \\
398,331 \\
413,536\end{array}$ \\
\hline Rhode Is.... & 428,556 & S. Dakota... & 401,570 & S. Carolina. & $1,340,316$ \\
\hline Vermont ... & $\mathbf{3 4 3 , 6 4 1}$ & & & $\begin{array}{l}\text { Tennessee } \\
\text { Texas } \ldots \ldots \\
\text { Vtah } \ldots \ldots\end{array}$ & $\begin{array}{r}2,020,616 \\
3,048,710 \\
276,749\end{array}$ \\
\hline & & & & $\begin{array}{l}\text { Virginla. } \\
\text { Washlagton } \\
\text { W. Virginia. } \\
\text { wisconsin. } \\
\text { Wyoming. }\end{array}$ & $\begin{array}{r}1,854,184 \\
518,103 \\
958,800 \\
2,069.042 \\
92,531\end{array}$ \\
\hline Total. . & $9,916,482$ & Total ... & $19,960,742$ & Total. ... & $46,117,351$ \\
\hline
\end{tabular}

Population, regiutration states, $1900 \ldots \ldots \ldots \ldots \ldots \ldots \ldots, 960,742$

Per cent. of total population $\ldots \ldots \ldots \ldots \ldots \ldots \ldots \ldots \ldots, 26.3$

Population, registration cities in states added, $1906 \ldots \ldots 3,835,119$

Per cent. of total population $\ldots \ldots \ldots \ldots \ldots \ldots \ldots \ldots \ldots$

Population of registration citles in nonregistration states. $6,969,757$

Per cent. of total population $\ldots \ldots \ldots \ldots \ldots \ldots \ldots \ldots \ldots, 9.2$

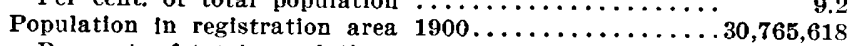

Per cent. of total population............... 40.5

Net population added to registration area in $1906 \ldots \ldots 6,081,363$

Per cent. of total population............... 8.0

Population in registration area in $1906 \ldots \ldots \ldots \ldots \ldots \ldots \ldots \ldots \ldots \ldots .846 .981$

Per cent. of total population .............. 48.5

NOTE.- Nearly all of the states not yet accepted as registration states have now, or have at some time possessed, laws Intended to secure the complete registration of deaths. These laws have usually been defective in principle, though in some instances faulty adminis. tration may have been responsible for fallure to secure results. Onl three states-Indiana, Maine and Michigan-were added to the registration area during the decade 1890 to 1900 , while one state-Delaware, which was admitted as a registration state in 1890 -was ware, which was admitted as a registration state In 1890-was
dropped from the lfst in 1900 . Two states-Nebraska and Utahadopted legislation in 1905 which requires immediate registration of deaths with compulsory burial permits, and it is boped that the results obtained will fustify their admission at an early date. In addition to the population of the registration states given above, it should be remembered that certain cities in states not yet accepted as registration states having an aggregate population of $6.969,757$ in 1900 are also embraced in the registration area, which makes the total population of that area on the basis of the census of 1900 amount to $36,846,981$. 
are conversant with the essential requirements of registration laws. ${ }^{1}$

I have said nothing in regard to the registration of births, because I believe the registration of births may, as a rule, best be promoted by first 'passing and enforcing an up-to-date law for the registration of deaths. This will enable all the necessary registration machinery to be organized, and the registration of births can be added after the registration of deaths has proved to be a practical success. The registration of births is most difficult-so much so that no state in this country, and no city, not even excepting cities like Boston and New York where laws have been in force for many years, has obtained complete returns of births. It is likely seriously to hamper the efforts to secure complete returns of deaths, and, as the mortality statistics are of greater sanitary importance, it would seem expedient, as a rule, to direct effort exclusively to the registration of deaths. Exception may sometimes be made with good results, as in Pennsylvania, where a completely organized and well-appointed system for births, deaths, and morbidity statistics as well, was installed, but if there is any doubt as to the ability to frame and to enforce a thoroughly effective law for the registration of deaths then legislation should be limited to what we know can be obtained under proper provisions.

The Bureau of the Census is coöperating with the various states in accordance with a joint resolution of Congress approved Feb. 11, 1903, which "requests the favorable consideration and action of the state authorities, to the end that the United States may attain a complete and uniform sustem of registration," and has sent many copies of its special publications on this subject, with the approval of the state public health authorities, to the officers of the state and countv medical societies which form a part of the American Medical Association. Their attention has been called to the following resolution, adopted by the Association at New Orleans in 1903. and it is hoped that the results shown by the vital statistics legislation of $190 \%$ will indicate the beneficial effect of the interest exhibited by the members of the Association:

Resolned, That the American Medical Assoriation strongly urges on the state merical societies that special committees be annointed to advocate and secure the passage of satisfactory registration laws in states that do not at present possess them. that county societies support and aid in the execution of such laws as far as possible. and that physicians individually, throughout the United States, endeavor to promote the accuracy and value of the mortality statistics by giving clear and definite statements of causes of death on certificates of death.

1. The following publications of the Bureau of the Census relating to this subject are avallable for distribution: No. 71. Registration of Deaths. Including a paper on "The Fssential Requirements tration of Deaths, Registration of Deaths and the Collection of Mor. of a Law for the Registration of Deaths and the collection of Mor. 104. Registration of Births and Deaths-Drafts of Laws and Forms of Certificates. No. 106. Extension of the Registration Area for Births and Deaths-A Practical Example of Co-operative Census Methods as Applled to the State of Pennsplvania. A general acconnt of the movement will also be found in the Introduction to the special report on "Mortality Stattstics. 1900 to 1904."

The Importance of Dietetics.-The various forms of food, the methorls and requirements of normal digestion, the influence of age and the adaptability of nutrition in the various diseases to which the human body is liable are subjects to which we can not urge attention too forcibly. It is not wise to urge too rigid a diet in any particular disease. We no longer absolutely discard meat in the nephritic nor sugar in the diabetic patient.-Medical Times.

\section{Clinical Notes}

\section{THE QUANTITATIVE DETERMINATION OF GLUCOSE IN THE URINE BY A NEW MODIFICATION OF FEHLING'S SOLUTION.}

J. RUDISCH, M.D., AND H. L. CELLER, M.D.

Attending Physician and Assistant in Pathological Laboratory, Respectively, in Mt. Sinal Hospital. NEW YORK CITY.

In the volumetric determination of glucose in urine based on the property of sugar to reduce cupric oxid the end reaction is markedly obscured by the precipitation of insoluble red cuprous oxid. To find a solvent for it has been the object of most of the modifications of Fehling's method thus far proposed.

The employment of an ammoniacal solution of cupric oxid to avoid this disturbing factor was first suggested by Pavy, whose method was subsequently modified by a number of investigators, including one of us ( $\mathrm{J}$. Rudisch). Such ammoniacal solutions, however, have not entirely accomplished their purpose. Not alone is the odor of ammonia obnoxious, but unless the determination proceeds rapidly the ammonia is driven off in sufficient quantity during the boiling to permit the deposit of the red oxid of copper before the end reaction is complete.

These disadvantages are overcome in the method devised by Gerrard and Allan. Ten c.cm. of a mixture of equal parts of Fehlings' copper sulphate and alkaline solutions are heated to boiling, and exactly or nearly decolorized by titration with a 5 per cent. solution of potassium cyanid. After the addition of another 10 c.cm. of Fehling mixture to the decolorized solution it is again heated to boiling, and the sugar-containing urine then titrated into it from a burette until the blue color of the added copper is again destroyed. The double salt of potassium and copper cyanid formed during the first titration suffices to keep the red cuprous oxid in solution. This method, involving, as it does, two titrations and extreme care in avoiding an excess of potassium cyanid, presents considerable difficulty to the clinical worker. The use of potassium cyanid, a highly poisonous substance, and the relative instability of the solution are further objections to its general use.

In the following method which we have devised the disadvantages of the Allan-Gerrard test are obviated. To four parts by volume of a 50 per cent. solution of potassium sulphocyanate, chemically pure, is added one part by volume of a mixture of equal parts of Fehling's copper sulphate and alkaline solutions. Twenty-five c.cm. of this solution are placed in a porcelain dish, and the urine to be tested added drop by drop from a burette until the blue color of the copper entirely disappears. Throughout the titration the solution should be slowly boiled and constantly stirred with a glass rod. The end reaction is extremely sharp, the fluid becoming colorless or assuming a faint yellow tinge. The advantages of this method are (1) only one titration is necessary as potassium sulphocyanate does not decolorize the copper solution; (2) potassium sulphocyanate is not poisonous; (3) as the mixture is stable a considerable quantity may be made to be kept as "stock." Such a "stock" solution was found to be unaffected after four months' exposure to heat and sunlight. 